\title{
Analysis of Top-Down Organizational Communication in Railway Companies in the Republic of Kosovo from the Employees' Perspective
}

\section{Gëzim QERIMI}

Department of Journalism

Faculty of Philology

University of Prishtina "Hasan Prishtina"

E-mail: gezim.qerimi@uni-pr.edu

\begin{abstract}
Organizational communication has always impacted organizational effectiveness and performance. Taking into account the importance of the railways, it is important to study this dimension in Kosovo's railway companies,. The railroad is regarded as the first media revolution and railways have revolutionized human life in general. The purpose of this research is to analyze the leaders-staff relationships in public institution in the Republic of Kosovo, in this case, Kosovo Railways companies, from an employee's perspective. In this study, data were collected from 312 employees in three railway organizations in Kosovo, Infrakos, Trainkos, and Railtrans. The survey questions have been raised based on the Communication Satisfaction Questionnaire. The results of the study show that the level of communication in all three companies is satisfactory, but the evaluation and performance of employees are not evaluated or it is ignored by managers. The results also show that supervisors and managers' instructions from the employees are positively evaluated, while employees consider that there is a lack of appreciation and staff feedback from the manager for their successes and work.
\end{abstract}

Keywords: Employees; Management; Media revolution; Organization communication; Railway companies; Top-down communication. 


\section{Introduction}

The main purpose of this paper is to explore the organizational communication in Kosovo's railway companies and how it affects their performance. In addition, the paper aims to establish an applicable and efficient model of organizational communication that can also be used in other public and private enterprises or organizations operating in the Republic of Kosovo. Through this paper, we will be given scientific answers to the following objectives:

1. Assess the level of internal organizational communication in Kosovo Railway Enterprises.

2. Analyze the realization of top-down communication in these organizations.

3. Examine the need for informal education in the staff of these organizations, especially at the managerial level, and design a module for internal organizational communication that would serve as a practice for other organizations in Kosovo.

The main research question is: How much do internal organizational communication and top-down communication influence the performance of Kosovo Railways companies? Thus, the purpose of this research is to analyze the leadershipstaff relationships in public institution in the Republic of Kosovo, in this case, Kosovo Railways companies, from the employees' perspective.

In support of the main research question the following research questions have been adressed:

i. What is the top-down communication role in motivating members and the performance of railway companies in Kosovo?

ii. How does supervisory oversight affect employees in railway companies of Kosovo and what is its impact on improving organizational communication?

\section{The reasoning for institutions' selection}

Railways have served to transport people and material goods. Through this transport, humanity is served to contact and communicate with each other. Many theorists have estimated that the railways have revolutionized human life in general. More specifically, the railroad is regarded as the first media revolution by Asa Briggs and Peter Burke (2009) in their book "A Social Media Story: From Gutenberg to the Internet". This argument has been an inducement to select Kosovo's railways, namely the three organizations dealing with this field in the Republic of Kosovo. Two of these enterprises are public: TrainKos and InfraKos, and one is private, RailTrans. To analyze top-down communication in these enterprises and to get closer to the way communication decisions are made and how they are expected from employees, the analysis was accomplished from the employees' perspective, excluding the management part of the concerned organizations. 
According to Briggs and Burke, the railroad has served as a medium far ahead of the transistor, and they call it the "media revolution" rail because it has set the system for those that have followed such as technology, economy, politics and management (Briggs \& Burke, 2009, 121). Given the importance of railways in the US industrialization and civilization, the corridors of many different companies located in the Silicon Valley (that is a high tech region in San Francisco, California, USA, where the headquarters of thousands of world tech companies are located, including Google, Apple, Facebook, Adobe, Cisco, Intel, HP, Samsung) lie with the snapshots of well-known American locomotives. Railways have also functioned in expanding and increasing cities due to ease of movement of people and goods. Canadian sociologist Marshall McLuhan in his book "Understanding Media", states that the railroad brought the development of suburban neighborhoods, where it could go home on foot from the railroad station. Shops and hotels around the railroad gave these neighborhoods concentration and shape (McLuhan, 1964, 202).

The message of any medium or technology is the change in the scale, rhythm, or pattern it presents in human affairs. Railways did not present a movement, transport, wheel or road to human society but accelerated and expanded the scale of earlier human functions by creating entirely new types of cities and new ways of working and entertainment in leisure. This happened even if the railroad operated in the tropical and northern areas, and is quite independent of freight transport or the content of the railroad medium (McLuhan, 1964, 8). What McLuhan writes about railways apply equally to print media, television and now to the Internet. "The medium is a message" because "the medium is the one who treats and controls the degree and form of human interaction and action" (McLuhan, 1964, 9). The importance of railways has inevitably led many sociologists and other scientists to deal with it and treat it as a phenomenon and have tried to give different theoretical views.

\section{Study Context}

The first railway line in Kosovo was constructed 145 years ago, in 1874, in train route: Hani i Elezit - Fushë Kosovë - Mitrovica (Infrakos, 2018). It was the beginning of the railway network throughout Kosovo, as important for the transportation of passengers and goods as equally crucial for the new dynamics of communication and movement of people as well as the economic development and the connection of Kosovo to the countries of the region and Europe. In 1931, construction of this line was continued in the Mitrovica - Leshak connection, in 1934 Fushë Kosovë - Prishtina, in 1936 Fushë Kosova - Peja, in 1949 Prishtina - Podujevë

- Livadhi and in 1963 Klinë - Prizren. So today, Kosovo Railways lie in the entire territory of Kosovo with a length of $333,9 \mathrm{~km}$ of open railway line, with a length of 
$105,7 \mathrm{~km}$ in stations and 103,4 km of industrial lines. Kosovo Railways through Leshak and Podujevo in the north and east are connected with Serbia, while through Hani i Elezit, south of Macedonia. The Law on Railways in the Republic of Kosovo foresees that infrastructure and operation in Kosovo Railways are separate (Infrakos, 2018).

In 2010, Kosovo Railways, owned by the Republic of Kosovo, were divided into two companies to meet the standards required by the European Union for a better operation of the Railways. According to Law No. 03 / L-076, the Government of the Republic of Kosovo decided on the division of Kosovo Railways into the Trainkos and Infrakos (Government Decision, 2010, 6).

Trainkos is responsible for assets, property and enjoys the rights and obligations arising from the division. The main activity is the transport of passenger goods and services on a commercial basis (Trainkos 2018). Meanwhile, Infrakos is responsible for the assets, property and enjoys the rights and obligations arising from this transformation. The main scope of the Infrakos is the management, maintenance, renovation and construction of railway infrastructure, the provision of services at the terminal of goods, etc. (Infrakos, 2018). Both of these railway enterprises are under the ownership of the Government of Kosovo, under the administration of the Ministry of Economic Development (Government Decision 2010).

The third company that is the subject of this study is Railtrans, which is the only private company in this field that operates in Kosovo. This company was established in May 2008 with 100\% private ownership and was created with the primary purpose of it to provide logistical services of international freight transport. Initially oriented to the organization of rail freight transport, but timely it has been expanded in all forms of transport by providing a full package of logistics and transportation services. The activity of this company is oriented to several business areas in order to make the best use of the capacities they possess and meet the market requirements in many areas, but what is in interest for the study is railway transport business, which is oriented towards heavy industry and mining, as well as towards other manufacturing and trading businesses in general (Railtrans, 2016).

\section{Theoretical framework}

According to Conrad and Cheney $(2018,19)$, “organizational communication's central purpose is to persuade employees to comply with managerial commands and to sublimate their interests and goals to those of the organization".

In terms of orientation, organizational communication can develop vertically, horizontally and diagonally. Within the formal organizational communication that is carried out in the vertical direction, also is top-down communication, which is evaluated as the most studied aspect of formal communication. Top-down com- 
munication involves transmitting messages from the highest to the lowest levels in the organizational hierarchy (Papa, Daniels \& Spiker, 2009, 48). This type of communication is the dominant part of communication in a given organization. Since the top part of the organization (senior management, management level), leads the organization and gives orders to subordinates, this mandate is top-down vertical communication over other members of the organization. Miller and Barbour emphasize the importance of horizontal communication, "is just as important as downward communication in the accomplishment of organizational goals" (Miller \& Barbour, 2014, 52).

Authors Daniel Katz and Robert Kahn $(1978,428)$ identified five types of messages that usually appear in top-down communication:

a. The concentration of group or organization objectives,

b. Clarification of organizational procedures and rules,

c. The argument of the work itself,

d. Working instructions and

e. Evaluation (Feedback).

The first point, the focus of organizational objectives, is also called indoctrination. This does not mean that only the objective of economic performance should be achieved, but the members of the organization should take an ideological approach to the culture and goals of an organization, with the objective of linking and identifying with the organization. Thus, it is not surprising that organizational engagement is a criterion of management success. Thus, a parallel can be drawn from Table 1 for the ranking of secondary communication functions: they contain social categorization, identification and enterprise culture (Le Borgne, 2012).

Table 1. Comparison of primary and secondary functions in Organizational Communication (Le Borgne 2012)

\begin{tabular}{|c|c|}
\hline Primary functions & Secondary functions \\
\hline $\begin{array}{l}\text { - Announcing and raising (public) awareness - the typical PR gig, } \\
\text { - Disseminating information (in various ways and for various au- } \\
\text { diences, from sending freebies, publications or newsletters to } \\
\text { partners and clients to sending press releases to the media), } \\
\text { - Sharing it both physically (at events) and online or virtually } \\
\text { through engaging sporadically with other people around a spe- } \\
\text { cific information, } \\
\text { - Engaging with audiences as a longer term structured process to } \\
\text { develop trust and share information more effectively - either as } \\
\text { part of an action research program, a multi-stakeholder process } \\
\text { or something else, } \\
\text { - And ultimately collaborating (assuming that a clear protocol of } \\
\text { cooperation and coordination is in place to allow that collabora- } \\
\text { tion to flourish). }\end{array}$ & $\begin{array}{l}\text { - Writing outputs (of all kinds), } \\
\text { - Documenting (either processes, con- } \\
\text { versations, work, protocols, etc.) which } \\
\text { prepares the way for the writing, } \\
\text { - Publishing and design, which is about } \\
\text { getting the written outputs to the next } \\
\text { level (design, peer review, etc.) and out, } \\
\text { - Training on a number of communication } \\
\text { channels and processes, } \\
\text { - And finally supporting in any other way } \\
\text { (coaching, informing, guaranteeing a } \\
\text { helpdesk function, etc.). }\end{array}$ \\
\hline
\end{tabular}


The second function is to clarify procedures and practices. In large organizations, organizational procedures are usually subject to an organizational manual or a staff manual, listing details of which actions should be respected and taken into account in certain situations. On the one hand, this obliges the leaders to oversee the compliance with these procedures, and on the other hand, it is incumbent on managers to transmit such procedures in the absence of an organizational manual. Practices, on the other hand, are desirable behaviors in the organization, such as adhering to specific dress codes and using security measures (Le Borgne, 2012)..

The justification for working in principle is a fundamental statement regarding the specific work and, in addition, what is the correlation between the goals pursued. This can also be described as a motivational feature. An understanding of the content of work and the importance of individual actions can lead to the concept of Herzberg (2008), which we had presented when we talked about organizations, about the satisfaction of work and motivation. Job satisfaction is another criterion for achieving successful management. Even at this point, we again refer to the secondary functions of communication.

The most frequent content of managers' communications is job instructions or recommendations about how to perform tasks. The importance of strong job guidance is also reflected in explicitly crafted exercises for the purpose of education in this regard. The work instructions contain the deployment and coordination of work-sharing activities.

Feedback is an important feature of leadership and any supervisory position as well as a central component in employee discussion with the aim of providing performance. This means that it corresponds to overseeing the primary function of communication review and improving the process for achieving the target, and serves as an essential auxiliary tool for managers, contributing to stimulate worker satisfaction and readiness for performance. The employee associates certain learning processes with feedback and, accordingly, changes his behavior and experience. This could be part of strategic initiatives as efforts that "aimed at employee commitment to the changes" (Salem, 2017, 109). Open and constructive feedback enhances communication and collaboration for one step more, between manager and employee.

It is worth pointing out that the earliest thinker of this type of formal communication is Max Weber, who believed there were two ways to force employees to follow the directives: power (power) and authority. Weber defined power as the ability to persuade employees with strength despite their resistance while considering authority as voluntary obedience (Weber, 2009; Wrench, 2012, 203).

However, this type of formal communication has its problems or shortcomings. Unfortunately, the message could be lost as it goes down. From a study done in 100 firms, it was proven that $80 \%$ of the message was lost, while running on five 
levels of the hierarchy of the organization (Sligo, 1995, 63). The message distortions deriving from top to bottom are of two types:

- An expression of the message in which the selective storage of the message by the recipients of each level prompted them to exaggerate certain portions of the message.

- Message leveling, or selective removal of other details (Manxhari, 2013, 323).

\section{Methodology}

Based on the purpose of the study, the analyse of the organizational communication in Kosovo railway companies, two hypotheses have been raised in this paper.

Hypothesis 1: Internal organizational communication is a factor that positively affects the performance of railway companies operating in Kosovo.

Hypothesis 2: Top-down communication does not affect the motivation of members and the performance of railway enterprises in Kosovo.

A survey of 312 questionnaires was conducted in 3 Kosovo Railway Organizations, two public enterprises, and one private company. The sample represents more than half of the total number of employees in the organizations: Trainkos, Infrakos, and Railtrans. Out of the 312 respondents in the three railway companies in Kosovo considered for the study, 160 are surveyed in Infrakos, 116 in Trainkos and 36 in Railtrans. After analyzing the data, there are three directions of the total of 5 alternatives that have been able to answer the respondents:

a. Positively (alternatives 1. fully agree, and 2. agree);

b. Neutral (alternative 3. I do not know) and

c. Negatively (alternatives 4. somehow I agree and 5. disagree).

The questionnaire was designed based on the Communication Satisfaction Questionnaire (CSQ) developed by C.W. Downs and Hazen (1977), as an attempt to detect interconnection between communication and work satisfaction, but is tailored to the specific circumstances and reality of organizations operating in Kosovo, excluding the element of satisfaction measurement at work and focusing entirely on internal organizational communication. CSQ is one of the most used instruments in the organizational communication studies and it includes the direction of information flow, the formal and informal communicationwithin the organization and relationships of members within organizations.

To respond to the research question, data have been collected from various levels of Kosovo Railways companies' employees. According to the analysis, the sample is dominated by males, aged 41-50, high school education and respondents with over ten years of experience. The following table (Table 2) shows the number of respondents by gender. This table also summarizes the demographic data of 
this study, such as the age of employees divided into several main age groups, the level of education and the working years in those institutions.

Table 2. Demographic characteristics of the sample (designed by the author)

\begin{tabular}{lrrrr}
\hline $\begin{array}{l}\text { Demographic } \\
\text { characteristics } \\
\text { of respondents }\end{array}$ & Infrakos & Trainkos & Railtrans & $\begin{array}{c}\text { TOTAL } \\
\%\end{array}$ \\
\cline { 2 - 5 } & N 160 & N 116 & N 36 & N 312 \\
\hline SEX & 9 & 12 & 4 & 8.01 \\
Women & 149 & 104 & 32 & 91.3 \\
Male & 158 & 116 & 36 & 99.3 \\
Valid & 2 & 0 & 0 & 0.7 \\
Missing & & & & \\
AGE & 25 & 23 & 8 & 17.9 \\
25-40 & 74 & 30 & 14 & 37.8 \\
41-50 & 43 & 50 & 14 & 34.3 \\
51-60 & 18 & 13 & & 9.9 \\
Over 60 & 160 & 116 & 36 & 100.0 \\
Valid & & & & \\
EDUCATION & 25 & 8 & 4 & 11.8 \\
Primary School & 101 & 61 & 20 & 58.3 \\
High School & 30 & 47 & 12 & 28.5 \\
University & 156 & 116 & 36 & 98.7 \\
Valid & 4 & 0 & 0 & 1.3 \\
Missing & & & & \\
WORK EXPERIENCE & 3 & 11 & 8 & 7.0 \\
Up to 5 years of work & 25 & 25 & 28 & 25.0 \\
5 - 10 years work & 132 & 80 & 0 & 67.9 \\
More than 10 years of work & 160 & 116 & 36 & 100.0 \\
Valid & & & & \\
\hline & & & & \\
\hline
\end{tabular}

Charles Redding, who is considered the father of organizational communication, has defined the pleasure of communication as "the total degree of satisfaction a worker perceives in the total communication environment" (Redding, 1966, 429). This paper is focused only on the component of internal organizational communication developed in these enterprises: top-down communication. Organization in these companies makes top-down communication more important, so the paper addresses only this part of the communication within the selected organizations in the study. The characteristic of this paper is the analysis of this type of communication from the perspective of employees.

\section{Results and discussion}

To the question information about the policies and goals of the department I work with is shared with me, in general, the outcome in all three companies is positive, as it is shown in the figure below (Figure 1). "Members must engage in to accomplish 
the process of organizing" (Mumby, 2012, 146) but to do so, every information about the department or the whole organization is important. This can be said to be practiced in the three companies involved in the study and the best result is in the public company 'Infrakos' with over $60 \%$. It indicates that the communication and circulation of information within the organization regarding the policies and goals of the structural parts (departments) of these companies are at a relatively good level

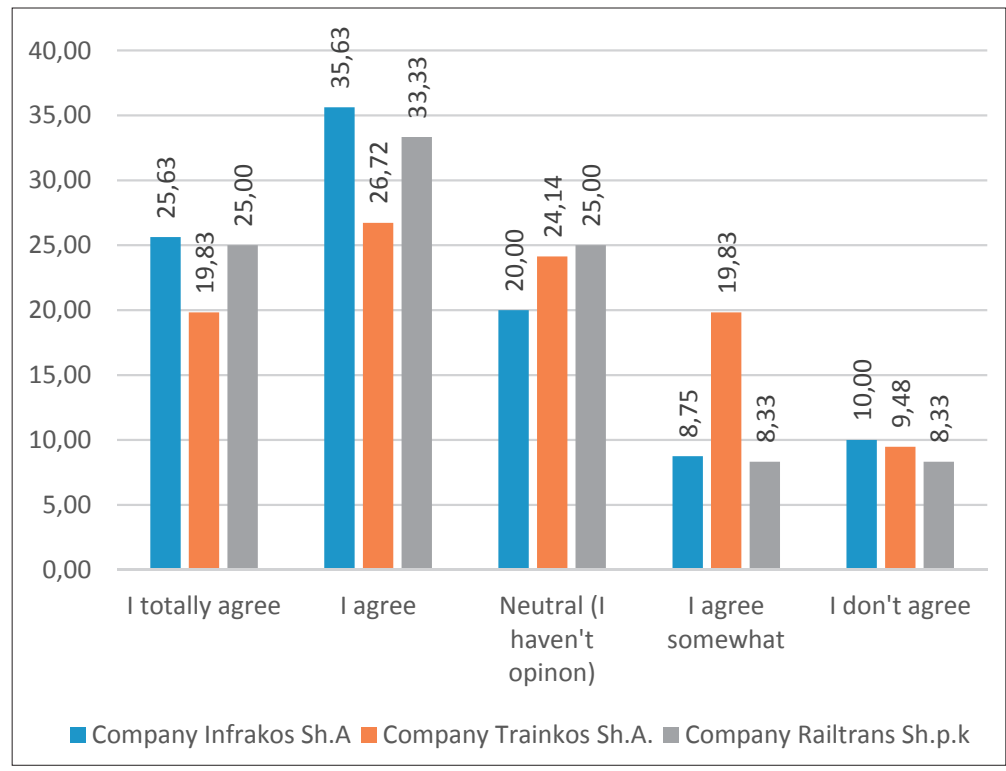

Figure 1. The information about the policies and goals of the Department where I work is shared with me (\%)

Excepting the positive results, respondents find that the information on the policies of the organizations is communicated relatively in time, as shown in Figure 1. Dilip Mookherjee $(2013,676)$ sees managers as "processors or generators of information which could be used by others in making decisions." In this matter, it is important for sharing information about the policies and goals of the company. Respondents have estimated that information on the organization's policies and goals is sufficient and timely disseminated, indicating an efficiency of communication in these organizations. Exceptionally, the result is negative to the public company Infrakos, where only $35.63 \%$ of employees of this company have positively evaluated the dissemination of information about the organization's policies and goals. 


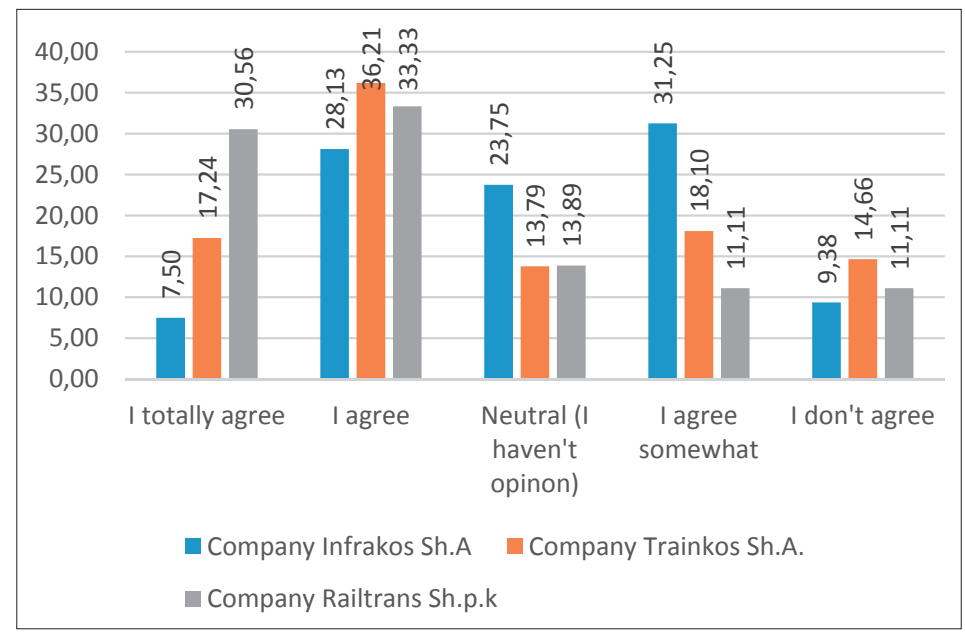

Figure 2. I am timely informed about the organization's policies and goals (\%)

It can be concluded that there is a positive correlation between sharing information about policies and goals of the company and timely informed about the organization's policies and goals in Trainkos and Railtrans. The more information about the policies and goals of the organization increases, the timely information on the same issues also increases. However, it is a negative correlation in Infrakos because although information about the policies and goals of the organization is positive, timely information is not. Around $40 \%$ of respondents from Infrakos think that they are not informed in time.

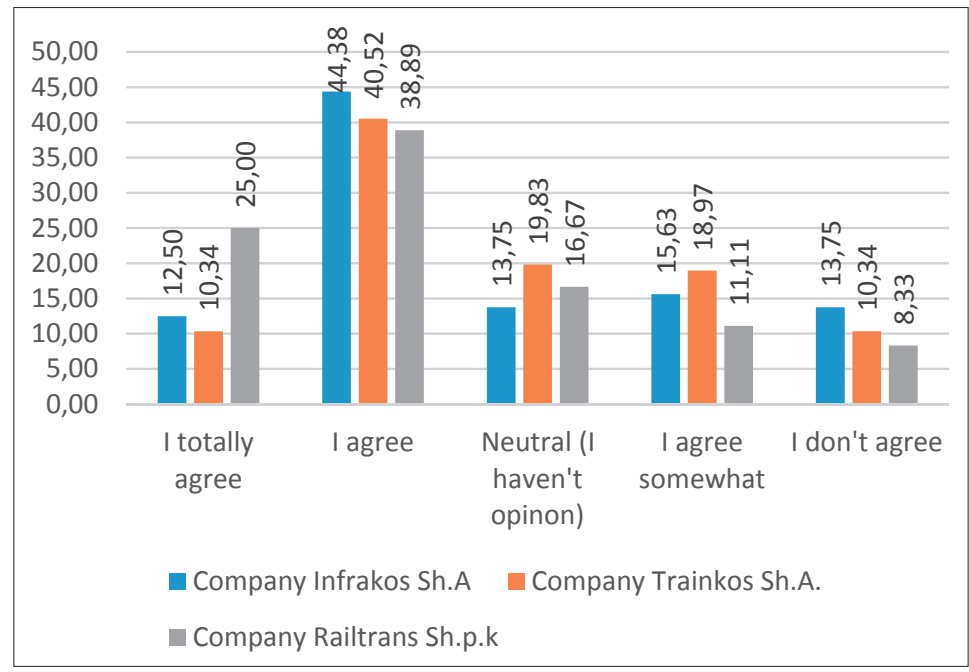

Figure 3. The supervisor provides support and guides me to overcome the potential challenges that I face during work (\%) 
Regarding the aspect of supervision and guidance in these three organizations, results show that the leading level of the three companies provides support and guides employees how to accomplish the job, perform the foreseen tasks and achieve the objectives. This is one of the three elements of an organization according to Barnard $(1938,83)$. Correlation between the manager support and employees' perception that have the right supervision is positive on both three companies.

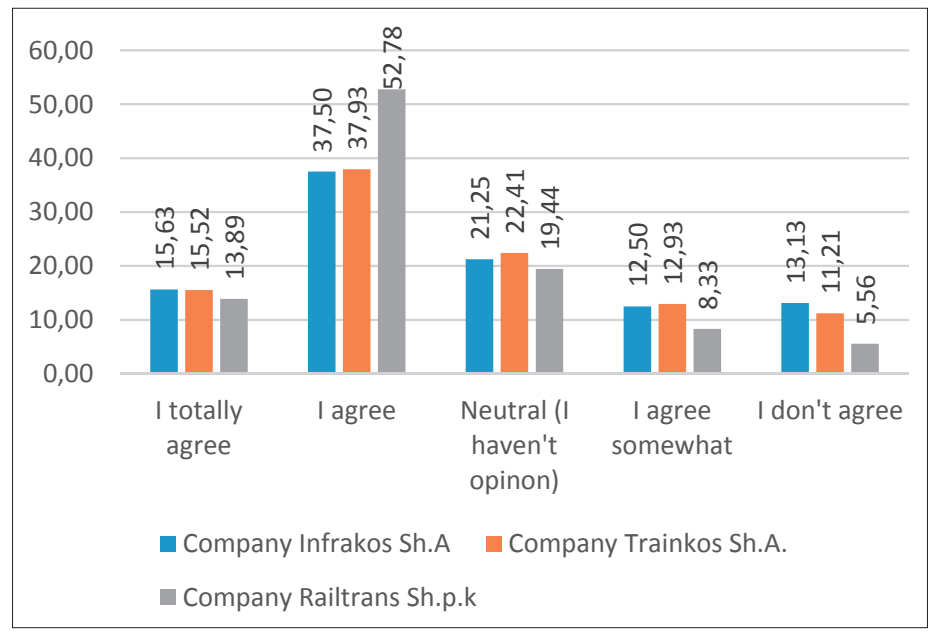

Figure 4. I have the right supervision (\%)

However, as can be seen in Figure 5, when talking about the appreciation of work acknowledgments and the distribution of success to others, from managers to their subordinates, the comparison of these results (Figures 2, 3 and 4) shows extreme controversy. The employees are positively assessed by supervision and guidance by managers, while they estimate that the appreciation and recognition of success for their work by the managers is lacking. This shows that top-down vertical communication does not function effectively and is not efficient at the desired level in all three companies.

If the results of the three companies in Figure 5 are compared, it turns out that the public company TrainKos is better in relation to the appreciation of the work of its employees and that this success is shared with others, which is considered to lead to a competitive and better performance within this organization compared to two other companies. Some scholars emphasize that organizations can use different methods to improve employee performance, such as respect (Ellingsen and Johannesson, 2007) and attention (Dur, 2009). According to surveys' results, it occurs that in the public company Trainkos, managers express more respect and attention to employees and as a result, employees are more satisfied with their managers. 


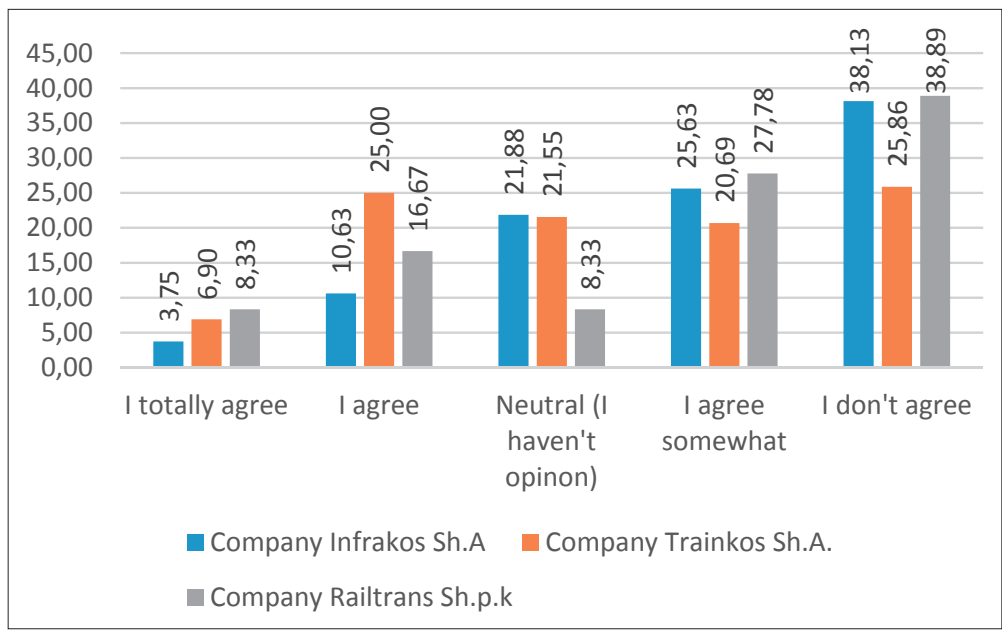

Figure 5. My work is valued with gratitude, and the success is distributed to others (\%)

In all three companies it is the positive outcome concerning directives and reports, which are considered to be clear and concise (Figure 6). In all three companies the positive rating is over $50 \%$. Meanwhile, the most favorable result for the directives and reports is in the public company Infrakos, namely $71.88 \%$.

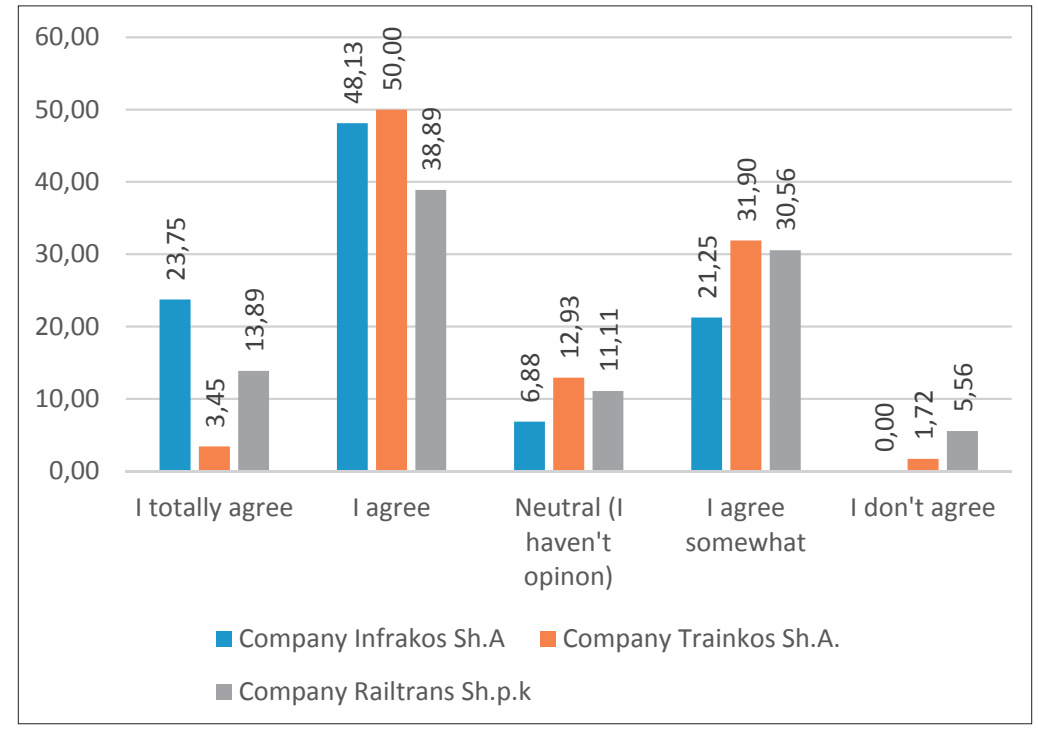

Figure 6. Directives and reports are clear and concise (\%)

If Figures 6 and 7 are compared, it can be concluded that employees in the three railway companies in Kosovo are informed about the assessment that others have for them (Figure 6), but this performance assessment is not taken seriously (Figure 7). 


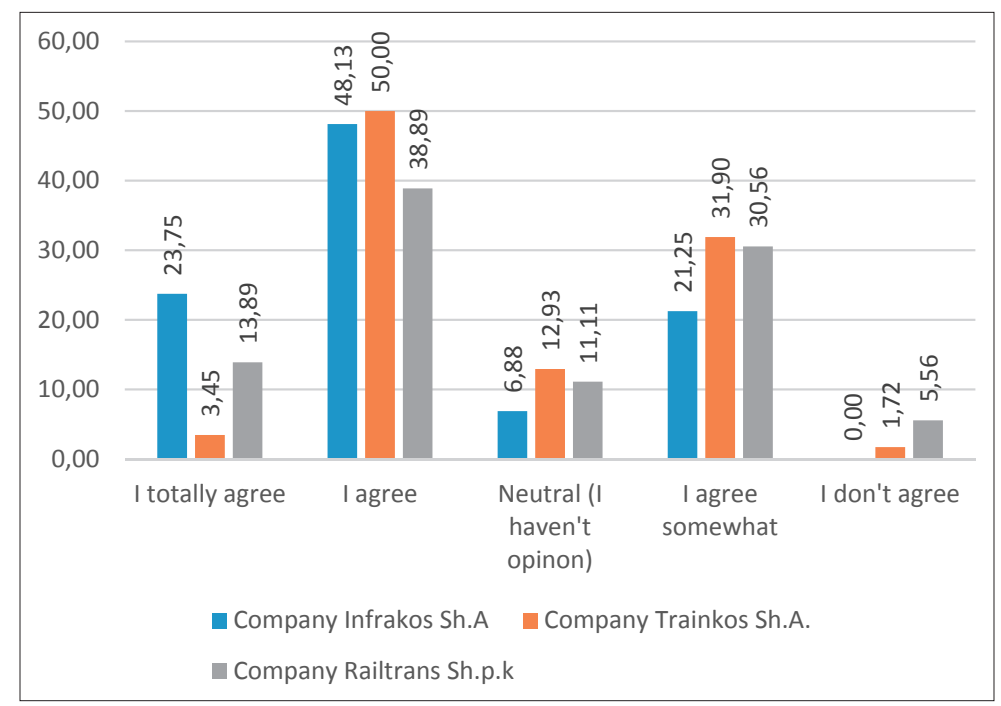

Figure 7. I am informed on how I was evaluated by others (\%)

Although an assessment of the work and performance of the employees is done, regardless of the evaluation, positive or negative, it, in the viewpoint of the employees, is not taken seriously by the managers and this feature later it does not apply either to the advancement of employees. About $58.38 \%$ out of 312 respondents reacted negatively, implying that performance appraisal is not taken

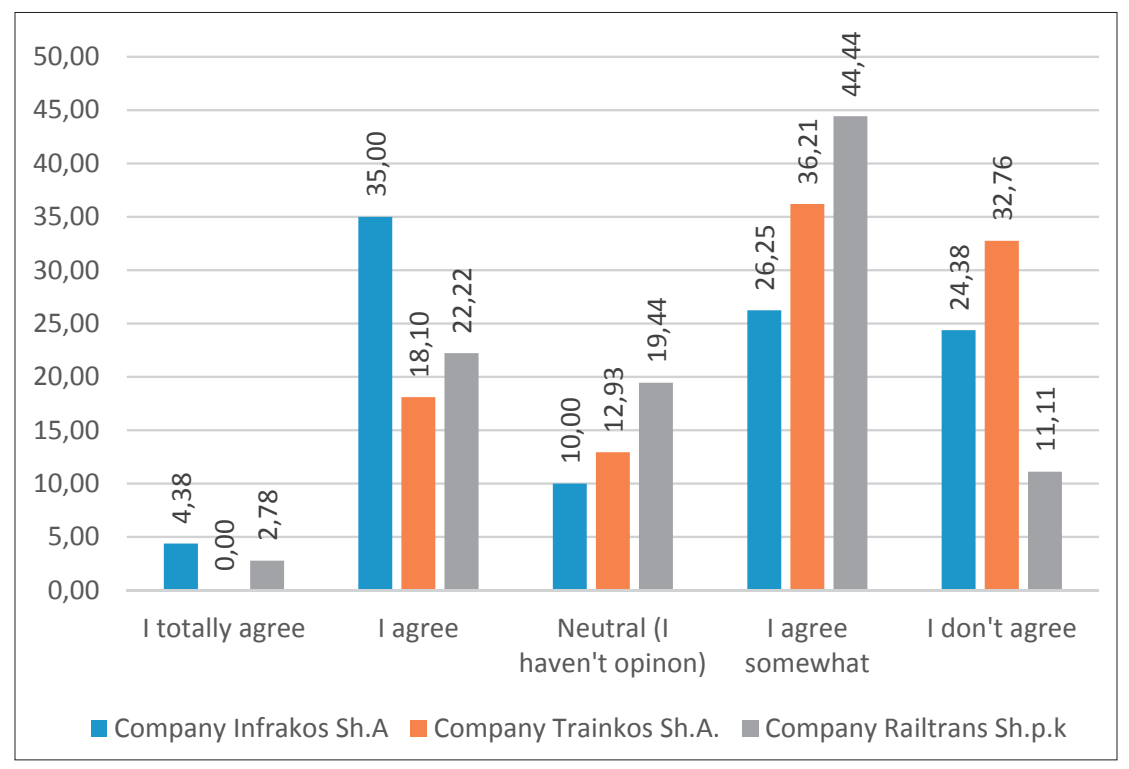

Figure 8. Performance evaluation is taken very seriously (\%) 
seriously by their managers. Gail Fairhurst and Stacey Cannughton $(2013,403)$ say that "physical distance did not influence communication effectiveness" but this ignorance from leaders could have a negative impact on communication effectiveness between employees and leaders.

Bies (2001) talks about the importance of sharing information from manager to employees stating that withholding information could create uncertainty among the employees. Withholding information also could result in less work motivation (Reb, Goldman, Kray, and Cropanzano, 2006). To prevent this, the manager should communicate as much as they can (Keye \& Jordan-Evans, 2008).

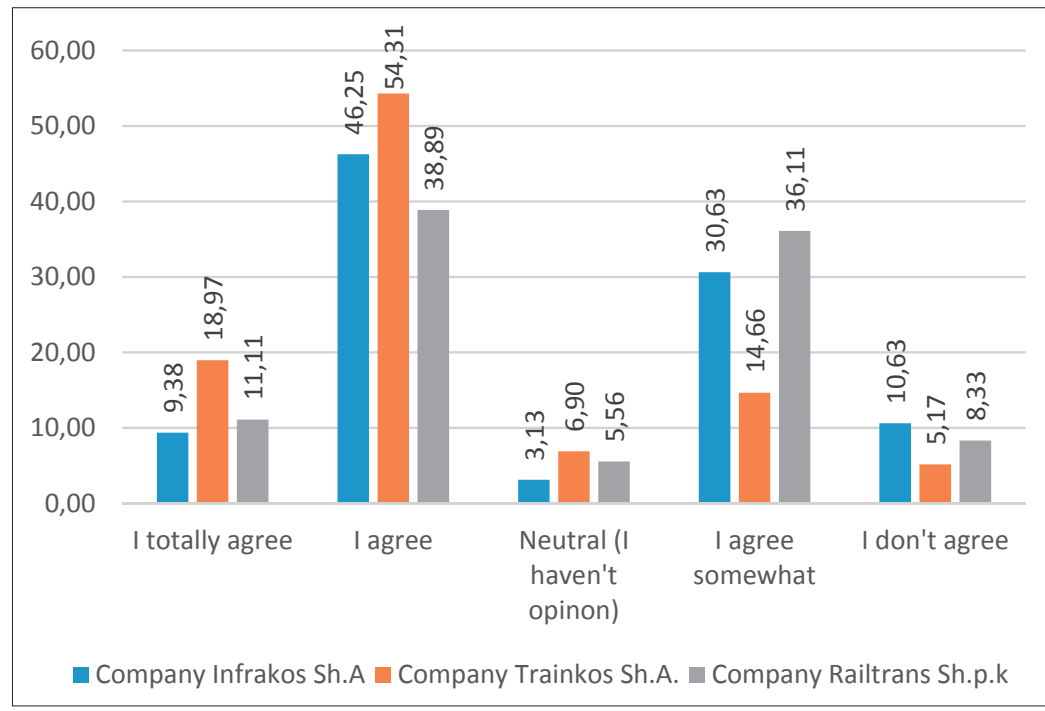

Figure 9. I receive timely the necessary information that I need for my work (\%)

Internal communication and information flow occur on time in three companies, and the overall score is over $50 \%$, which is also confirmed by data on Figure 1. Trainkos has had a financial crisis in recent years, and as a result, many information has been distributed among the employees to manage the situation better. During this period, Trainkos has had ongoing negotiations with the Kosovo government to manage the financial crisis. Therefore, the managers of this company, during this period, have been almost entirely open to the employees in order to keep up the motive for work and productivity at work. This also justifies the outcome of the survey for Trainkos, which is more positive compared to the other two companies.

Regarding the issue of informing the employees about the financial status of the organizations, data show that in the railway sector in Kosovo, public companies have a more transparent communication with their employees as well as with 
the outside public. It can be expained by the existance of legislation claiming that financial statements in public enterprises must be published, since they (Infrakos and Trainkos) are funded by public money (citizens' taxes).

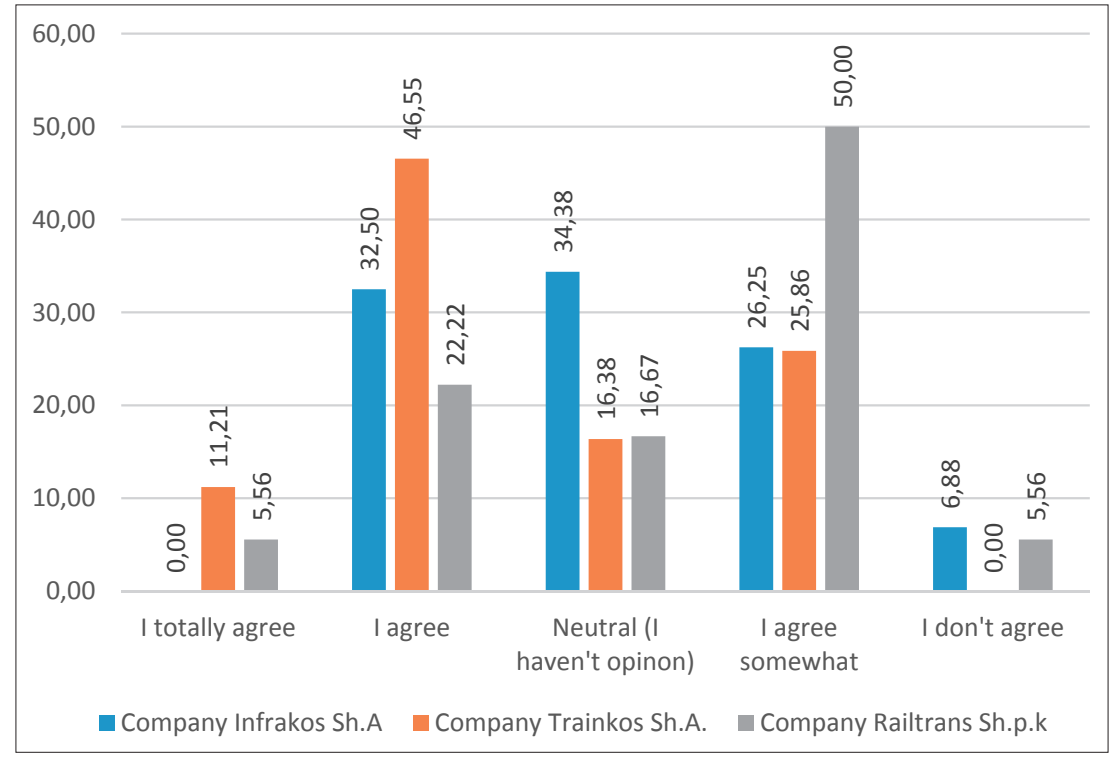

Figure 10. I am informed about the financial status of the organization (\%)

Correlation between timely informed and information about financial issues differs on three companies. Relationship is positive in Trainkos where most of the respondents say that they are timely informed in general, about politics and organization's goals and about the financial standing as well. In Railtrans, correlation is negative because employees in this company are timely informed but they do not have information about financial issues. Railtrans is a private company, therefore, it is common that information about financial issues are not shared with employees, as much as in a public company (e.g., Trainkos). Relationship is also negative in the case of Infrakos. In this company, managers share information with employees about politics and organization's goals but they are more reserved when it comes to discuss or share information about financial issues.

Informing employees on the financial situation of the organization is considered an indispensable information that influences the motivation of the employees as well as the creation of a common spirit for an incentive to accomplish the work, common interests and achievement of the organization's objectives. 


\section{Conclusion}

Starting from the first research question (How much does internal organizational communication and top-down communication influence on the performance of Kosovo Railways companies?) and surveying 312 employees of three railway organizations in Kosovo (Infrakos, Trainkos, and Railtrans) it is noted that the level of communication is satisfactory. However, the evaluation and performance of employees is not assessed or it is ignored by managers.

The first hypothesis of the paper is confirmed. The survey and analysis show that internal organizational communication is a factor that positively affects the performance of railway companies operating in Kosovo. Data show that internal communication affects the performance of the organization in general. The positive evaluation of employees for sharing information in the organization shows the fact that the internal circulation of the organization's policies and goals is positive and for them, it has an impact on the organization's performance.

The second hypothesis, stressing that top-down communication does not affect the motivation of members and the performance of railway companies in Kosovo, is confirmed. From the analysis of the data it can be concluded that employees are not satisfied with supervisory oversight. However, they are committed to the company, they are motivated, and communication effectiveness between employees and leaders remain the same, in a satisfied level.

Considering the second research question (How does supervisory oversight affect employees in railway companies of Kosovo and what is its impact on improving organizational communication?), we can conclude that the leadership of the three companies provide support and instruct employees how to accomplish the job, perform the foreseen tasks and achieve the objectives. Nonetheless, when talking about the appreciation of work acknowledgments and the distribution of success to others, from managers to their subordinates, the comparison of these results shows extreme controversy. While supervisors and managers' instructions from the employees are evaluated positively, employees consider that there is a lack of appreciation and staff feedback from the manager for their successes and work. This indicates that top-down vertical communication is realized and developed in the ordinary course, but there is no feedback rating assessment from the managers. In this case, it can be said that top-down communication does not function effectively and is not efficient at the desired level in all three companies estimated in terms of employee prospects.

It is essential to keep in mind that the study did not explore communication in railways companies from the managers' perspective. Hence, the top-down communication between managers and employees should be addressed in future research to examine the leadership style used in those companies and whether that style has influenced the organization's effectiveness. 


\section{References}

1. Barndard, Ch. (1938). The functions of the executive. Cambridge, MA: Harvard University Press.

2. Bies, R. J. (2001). Interactional (in)justice: The sacred and the profane. In J. Greenberg \& R. Cropanzano (eds.) Advances in organizational justice, California: Stanford University Press.

3. Briggs, A. \& Burke, P. (2009). A Social History of the Media: From Gutenberg to the Internet, Cambridge: Polity.

4. Buzzanell, P. \& Stohl, C. (1999). The Redding tradition of organizational communication scholarship: W. Charles Redding and his legacy. Communication Studies, 50(4): 324-336.

5. Conrad, Ch. \& Cheney, G. (2018). Organizational Communication and Organizational Rhetoric I: The Theme of Merger. In O. Ihlen \& R. L. Heath (eds.) The handbook of organizational rhetoric and communication, NJ: John Wiley \& Sons.

6. Dur, R. (2009). Gift Exchange in the Workplace: Money or Attention?. Journal of the European Economic Association, 7: 550-560.

7. Ellingsen, T. \& Johannesson, M. (2007). Paying Respect. Journal of Economic Perspectives, 21: 135-150.

8. Harris, Th. E., (2002), Applied Organizational Communication-Principles and Paradigms for Future Practice, London: Lawrence Erlbaum Associates.

9. InfraKos (2018). Ekspozeu i rrjetit. Retrieved from http://infrakos.com/wp-content/ uploads/2018/10/EKSPOZEU-I-RRJETIT-2019.pdf, on January 13, 2019

10. Fairhurst, G. \& Cannughton, S. (2013). Leadership Communication. In L. Putnam \& D. Mumby (eds.), The SAGE Handbook of Organizational Communication: Advances in Theory, Research, and Methods, 3rd edition, California: Sage.

11. Jakupi, A. (2005) Metodologjia e punës shkencore kërkimore, authorised lectures, Prishtinë.

12. Jefkins, F. (1987). International Dictionary of Marketing and Communication, London: Blackie and Son.

13. Koxhaj, A. \& Tomini, F. (2011), Manaxhimi i Komunikimit, Tiranë: albPAPER.

14. Le Borgne, E. (2012). Power your communication with 'KM inside'. Retrieved from https://km4meu.wordpress.com/2012/03/26/power-your-communication-with-kminside/ on December 17, 2018.

15. Herzberg, F. (2008). One More Time: How Do You Motivate Employees?, Harvard: Harvard Business School Press.

16. Keye, B., \& Jordan-Evans, S. (2008). Love 'em or lose 'em. California: Berrett Koehler Publishers.

17. Manxhari, M. (2013). Sjellja në Organizatë - Kuptimi dhe Menaxhimi i Aspektit Njerëzor të Organizatës, Tiranë: albPAPER.

18. McLuhan, M. (1964). Instrumentat e Komunikimit: Media si zgjatim i njeriut, Tiranë: Instituti i Dialogut dhe Komunikimit. 
19. Miller, K \& Barbour J. (2014). Organizational Communication: Approaches and Processes, 7th edition, USA: Cengage Learning;

20. Mookherjee, D. (2013). Incentives in Hierarchies. In R. Gibbons \& J. Roberts (eds.), The Handbook of Organizational Economics, New Jersey: Princeton University Press.

21. Mumby, D. (2012). Organizational Communication: A Critical Approach, London: Sage.

22. Ollivier, B. (2015). Shkencat e Komunikimit - Teori dhe arritje, Tiranë: Papirus.

23. Papa J. M., Tom, D. \& Barry, S. (2009). Komunikimi organizativ qasjet dhe pritjet, Tiranë: UETPress.

24. Popper, K. R. (2009). "Për filozofinë dhe shkencën”, Tiranë: ShtëpiaBotuese “Fan Noli”.

25. Postolov, K. \& Drakulevski, L. (2010). Organizimi - Drejtimi ekonomik, juridik dhe tregtar, Ministria e Arsimit dhe Shkencës e Republikës së Maqedonisë, Shkup.

26. Putnam, L. \& Mumby, D. (2013). The SAGE Handbook of Organizational Communication: Advances in Theory, Research, and Methods, 3rd edition, California: Sage.

27. Reb, J., B. Goldman, M., Kray, L. J. \& CropanzanoR. (2006). Different Wrongs, Different Remedies? Reactions to Organizational Remedies After Procedural and Interactional Justice. Personnel Psychology, 59: 31-64.

28. Redding, Ch. (1966). The empirical study of human communication in business and industry. In P. Reid (ed.), Frontiers in Experimental Speech Communication Research, New York: Syracuse UniversityPress.

29. Richmond, V. P., \&McCroskey, J. C. (2009). Organizational communication for survival: Making work, (4th ed.). Boston: Allyn \& Bacon.

30. Rouse, M. \& Rouse S. (2008). Komunikimet afariste - Qasje kulturologike dhe strategjike, Universiteti VICTORY \& Instituti i Hulumtimeve Shkencore, Prishtinë: Victory.

31. Salem, P. J. (2017). Transformative Organizational Communication Practices. In P. J. Salem \& E. Timmerman, Transformative Practice and Research in Organizational Communication, USA: IGI Global.

32. Sligo, F. (1995). Information Loss Revisited: How different levels of staff perceive their acces to work-related knowledge. Asia Pacific Journal of Human Resources, 33(1): 60-74.

33. Swanson, R. A., \& Holton, E. F. (2001). Foundations of human resource development. San Francisco: Berrett-Koehler.

34. Trainkos (2018). Plani i biznesit 2019. Retrieved from http://www.trainkos.com/wpcontent/uploads/2018/10/Plani-i-Biznesit-2019.pdf on January 13, 2019.

35. Weber, M. (2009). The Theory of Social and Economic Organization, New York: Simon and Schuster.

36. Wolton, D. (2009). Të shpëtojmë komunikimin, Tiranë: Papirus.

37. Wrench, J. S. (2012). An Introduction to Organizational Communication. Retrieved from https://2012books.lardbucket.org/pdfs/an-introduction-to-organizational-com munication.pdf on January 2019. 